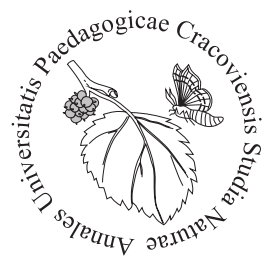

Klaudia Świacka, Alicja Michnowska*, Jakub Maculewicz, Izabela Przednowek, Iga Ogrodowczyk, Sebastian Kozic

Institute of Oceanography, University of Gdańsk, Gdynia, Poland; *alicja.michnowska@ug.edu.pl

\title{
Composition of phytoplankton in the Puck Bay and the open Baltic Sea
}

Introduction

The biocenosis of the Baltic Sea is an unusual combination of freshwater and ocean flora and fauna. The number of flora and fauna adapted to life in the brackish water is small, but there may be large quantities of individual species. Compared to the oceans, the food chains in the Baltic Sea are simple. The number of species reduces from the southern Baltic Sea to the north. The low salinity of the northern Baltic Sea, the cold winters, and the sea freezing over set challenges for the adaptation of organisms. Due to the slow water turnover, environmental toxins and eutrophying nutrients remain in the Baltic Sea and cause long-term effects (Olli et al., 2011).

The Puck Bay $\left(54^{\circ} 40^{\prime} 00^{\prime \prime} \mathrm{N} ; 18^{\circ} 35^{\prime} 00^{\prime \prime} \mathrm{E}\right)$ is an isolated part of Gulf of Gdańsk, separated by Hel Peninsula. The Bay has frequently been the subject of marine biological and hydrological research. This area has specific hydrological conditions. Due to the fact that the most of the Puck Bay is shallow, a greater effect of wind on the water dynamics is observed in this area. Thus anemobaric conditions in particular contribute to the movement of water masses. In the Puck Bay, a greater correlation between air and surface water temperatures is also observed, where rapid changes of surface water are triggered by changes in air temperature. Therefore, the composition and distribution of phytoplankton in this area differ significantly during the year (Klekot, 1980; Pliński, Picińska, 1985).

Phytoplankton blooms are a poorly studied phenomenon. It is in general connected with seasonal changes of sun irradiance affecting water temperature thermocline forming and some other environmental or anthropogenic factors, as local hydrography, and the increases inflow of pollutants (Żmijewska et al., 2000). Phytoplankton constitutes an elementary component in aquatic ecosystems. Representing the base of the pyramid of productivity, the understanding and modelling of the aquatic eco- 
system is not possible without knowledge of the species composition, productivity, and the biomass of phytoplankton. These changes in phytoplankton may reflect major shifts in environmental conditions (Olenina et al., 2006). In order to better understand the algal blooms, seasonal monitoring is necessary.

Due to natural and methodological reasons, the composition and abundance data on phytoplankton species are highly variable, and consequently, their use as water quality indicators is usually restricted, and mostly chlorophyll $a$ concentrations and primary production are monitored (e.g., SatBałtyk). Moreover, due to development in taxonomical classification and methodology, sufficiently long comparable time series of phytoplankton are rare (Suikkanen et al., 2007).

The aim of this study was to investigate and compare the composition of phytoplankton and the concentration of photosynthetic pigments on four selected stands located in the inside part of The Puck Bay and open water of the Baltic Sea. In the present research, quantitative and qualitative methods were used.

For qualitative analysis, samples were analysed by microscope (Nicon Eclipse 80i). Every observed individual of phytoplankton was identified to the genus or species level using specified keys for Baltic species of phytoplankton (Pliński, 1980) and noted.

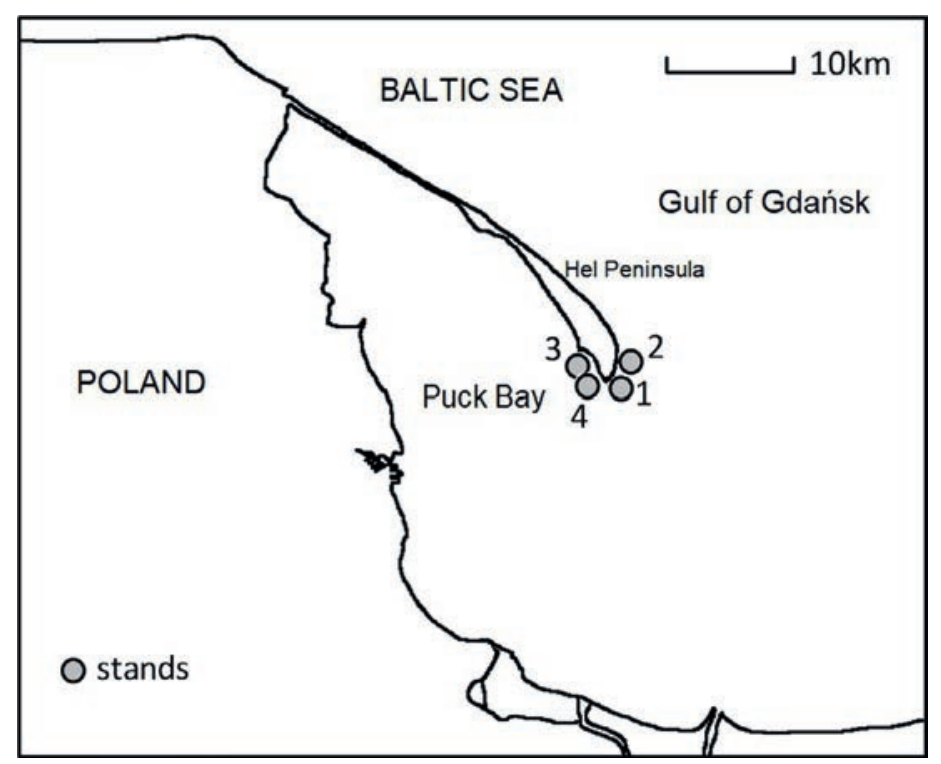

Fig. 1. Location of the study area: the open sea (Stands: 1,2) and the Gulf of Gdańsk (Stands: 3, 4)

\section{Material and methods}

The main parameters investigated in the present study were the composition of phytoplankton expressed as the presence of the identified genera or species on each stand 
and the concentration of photosynthetic pigments: chlorophyll $a, b$, and $c$ expressed in $\mu \mathrm{g} \cdot \mathrm{L}^{-1}$. To investigate the composition of phytoplankton, a qualitative method was used. To analyse the concentration of photosynthetic pigments, the quantitative method was used.

The investigation was conducted on a phytoplankton community collected once from the coastal zone in Poland of the open sea (Stands: 1,2) and the Gulf of Gdańsk (Stands: 3, 4), in July 2017 (Fig. 1). The plankton samples for qualitative analysis were collected from the surface layer using a phytoplankton net with a diameter of $24.5 \mathrm{~cm}$ and $50 \mu \mathrm{m}$ mesh size. For quantitative analysis, samples were also collected from the surface layer using 5 plastic containers which were filled with $1 \mathrm{~L}$ of water.

The concentration of photosynthetic pigments was measured using a spectrophotometric method. For quantitative analyses the samples were filtered $(\mathrm{V}=1 \mathrm{~L})$ through MN GF- 5 glass fibre filters and extracted with $5 \mathrm{ml}$ cold $90 \%$ acetone and then frozen at a temperature of $-20^{\circ} \mathrm{C}$ for 30 minutes. To remove cell debris and filter particles, the pigment extract was centrifuged at $10000 \mathrm{rpm}$ for 5 minutes. The extinction was determined at $\lambda_{\mathrm{m}} 630,647,664$, and $750 \mathrm{~nm}$ with a DU530 UV-VIS spectrophotometer (Beckman) using $1 \mathrm{~cm}$ glass cuvette. The concentration of pigment content was calculated in accordance with Jeffrey and Humphrey (1975). The measurement of photosynthetic pigment concentration was conducted in triplicate.

\section{Results and discussion}

The studied phytoplankton community was composed of different representatives of Cyanobacteria, Bacillariophyta, Pyrrophyta, and Chlorophyta (Tab. 1). In total, 17 taxa were observed on all stands, of which 14 were as a genus rank and 3 as a species rank (Fig. 2). The highest number of phytoplankton representatives was observed in Stand 1, where 12 generas were noted. Aphanizomenon flos-aquae, Chlorella vulgaris, and Navicula sp. were the only taxa noted on every stand. Leptolyngbya sp. and Chlorococcum sp. were observed only in Stand 1, while Coscinodiscus sp. and Oscillatoria sp. were noted exclusively in Stand 3.

The concentration of chlorophyll $a$ was highest in Stand 4 and reached $2.01 \mu \mathrm{g} \cdot \mathrm{L}^{-1}$ (Fig. 3). In the other stands, chlorophyll $a$ content was similar, and reached around 1.5 $\mu \mathrm{g} \cdot \mathrm{L}^{-1}$. Both concentrations of chlorophyll $b$ and $c$ were the lowest in Stand 2. The highest concentration of chlorophyll $b$ was in Stand 1 and reached $0.28 \mu \mathrm{g} \cdot \mathrm{L}^{-1}$, while the highest concentration of chlorophyll $c$ was in Stand 3, reaching $0.45 \mu \mathrm{g} \cdot \mathrm{L}^{-1}$. However, the concentration of chlorophyll $c$ in Stands 1, 3, and 4 was similar. In all investigated stands, the concentration of chlorophyll $a$ was much higher than the concentration of other types of chlorophyll. 


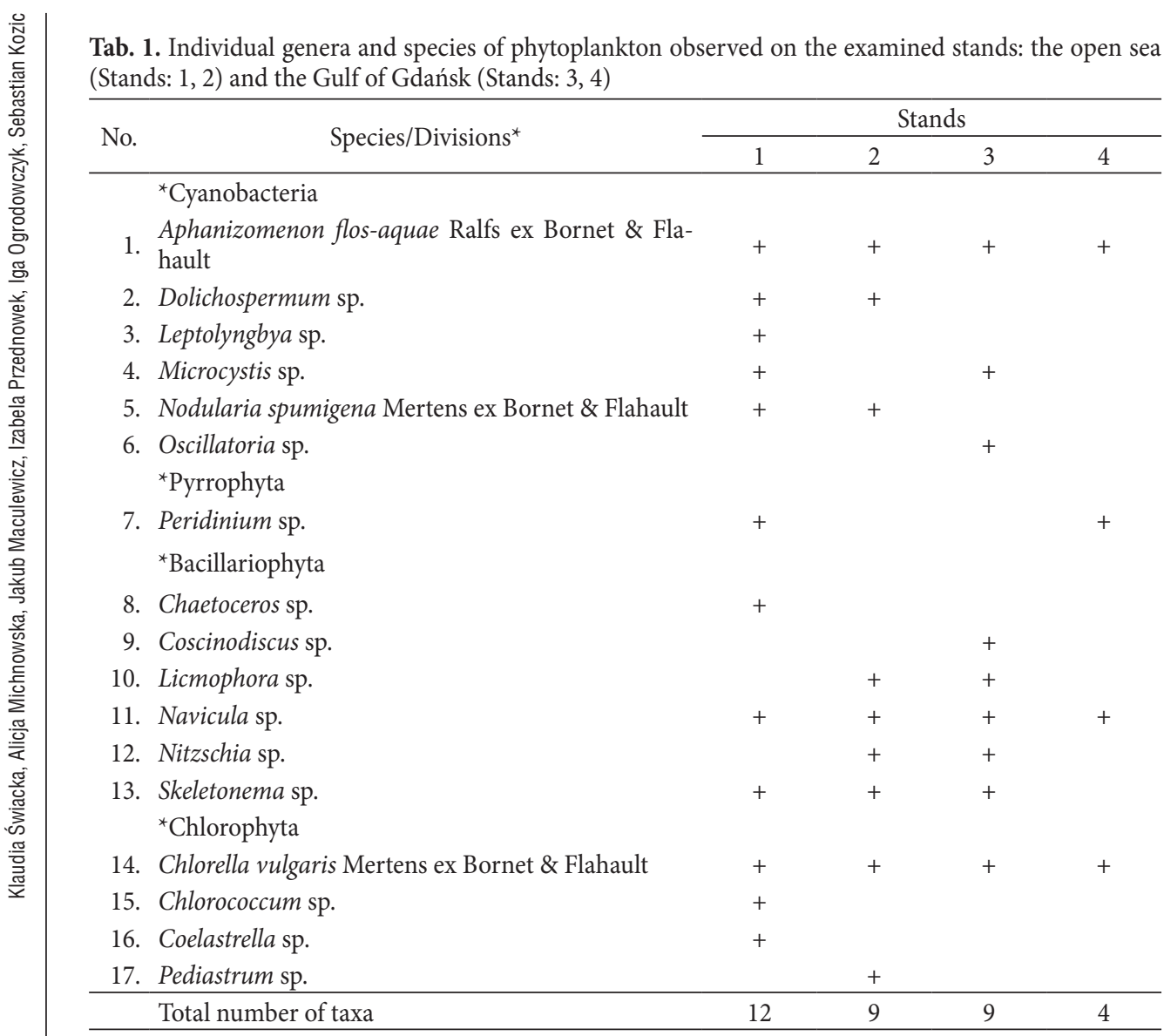

In the Baltic Sea during the summer months, cyclically observed phenomenon are the blooms of cyanobacteria, mainly of the order Nostocales. Nodularia spumigena and Aphanizomenon flos-aquae are the most often noted species which are the main components of summer blooms (Mazur-Marzec et al., 2012). Diatom blooms during spring and the huge uptake of biogenic compounds cause the decrease of those substances during summer, which makes the environmental conditions favourable for Cyanobacteria. During the deficiency of biogenic compounds, some species of Cyanobacteria are capable of fixing atmospheric nitrogen. The ability of fixing atmospheric nitrogen by some species of Cyanobacteria gives them predominance in the competition for space and environmental resources. Therefore, the heterocytous organisms can rapidly increase their biomass in short periods of time even under conditions of inorganic nitrogen deficiency (Mazur-Marzec et al., 2012; Wasmund et al., 1998).

In Stand 2, the lowest concentration of chlorophyll $c$ and $b$ was observed, which may indicate the lower abundance of Bacillariophyta and Chlorophyta. Out of the 


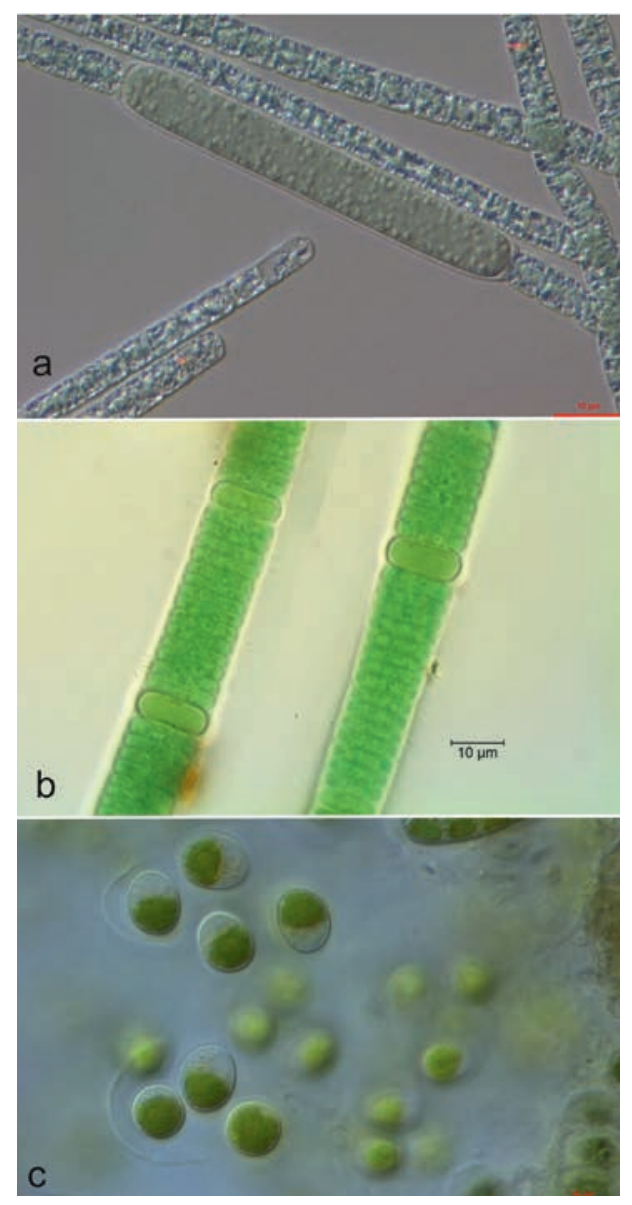

Fig. 2. Some species of Baltic phytoplankton: a - Aphanizomenon flosaquae Ralfs ex Bornet \& Flahault, b - Nodularia spumigena Mertens ex Bornet \& Flahault, c - Chlorella vulgaris Beyerinck [Beijerinck] (Source: AlgaeBase - Guiry, Guiry, 2017)

groups of algae that were identified, only Chlorophyta contains chlorophyll $b$ in chloroplasts, while chlorophyll $c$ is characteristic for Bacillariophyta (Jeffrey, Vesk, 1997; Kuczyńska et al., 2015). A high concentration of chlorophyll $a$ and a relatively low concentration of chlorophyll $b$ and $c$ may also indicate the domination of Cyanobacteria and simultaneously a decrease in diatoms in the Gulf of Gdansk. Moreover, sampling was taken in June when the measured temperature of surface water was of approximately $20^{\circ} \mathrm{C}$, which induce blooms of blue-green algae (Fleming, Kaitala, 2006). The differences in the concentration of chlorophyll $b$ between all stands may be connected with the differences in the composition of phytoplankton, which is also indicated by present results (Fig. 3; Tab.1). A low concentration of chlorophyll $c$ in Stand 2 may suggest the lower biomass of Bacillariophyta on this site. 


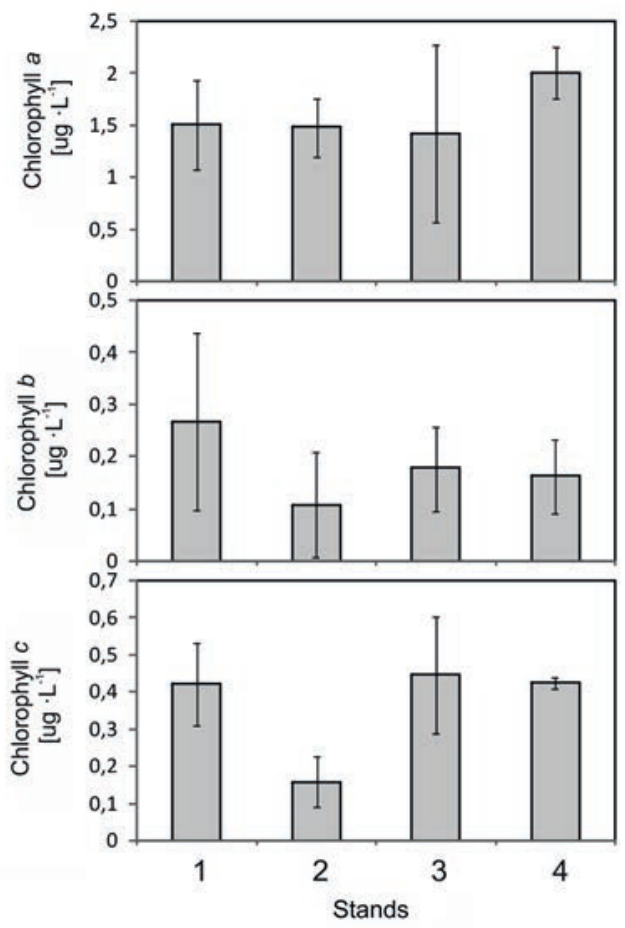

Fig. 3. The concentration of chlorophylls $a, b, c$ on the examined stands: the open sea (Stands: 1 , 2) and the Gulf of Gdańsk (Stands: 3, 4)

Unfavourable weather conditions (strong wind) probably contributed to the lower number of observed phytoplankton species. In the first stand on the end of the Hel Peninsula, the highest numbers of phytoplankton species were observed, which can be connected with the stable conditions during sampling. The species observed in all stands were A. flos-aquae and C. vulgaris. These species are widespread and often noted in the Gulf of Gdańsk and also in the open water of the Baltic Sea (Mazur-Marzec et al., 2012).

Large quantities of Aphanizomenon flos-aquae may contribute to the high concentration of chlorophyll $a$, even in stands characterised by a lower number of observed species of phytoplankton. Many observations suggest that A. flos-aquae produce some compounds that may alter plankton composition and activity, although each strain of this species may have different properties (Mazur-Marzec et al., 2012). There are also reports on the ability of these algae to affect various aquatic organisms, e.g., microalgae, but every target species may respond differently to the allelopathic activity (Keating, 1978; Ikawa et al., 1994; Kearns, Hunter, 2000). Taking into the account potentially harmful effects of algal blooms, persistent monitoring programs must be taken into consideration (Żmijewska et al., 2000). 


\section{References}

Fleming, V., Kaitala, S. (2006). Phytoplankton spring bloom intensity index for the Baltic Sea estimated for the years 1992 to 2004. Hydrobiologia, 554(1), 57-65. DOI: 10.1007/s10750-005-1006-7

Guiry, M.D., Guiry, G.M. (2017). AlgaeBase. World-wide electronic publication. Aphanizomenon flosaquae Ralfs ex Bornet \& Flahault, Nodularia spumigena Mertens ex Bornet \& Flahault, Chlorella vulgaris Beyerinck [Beijerinck]. Galway, Ireland: National University of Ireland, http://www.algaebase.org.

Ikawa, M., Haney, J.F., Sasner, J.J. (1994). Inhibition of Chlorella growth by the lipids of cyanobacterium Microcystis aeruginosa. Hydrobiologia, 331, 167-170. DOI: 10.1007/BF00025418

Jeffrey, S., Vesk, M. (1997). Introduction to marine phytoplankton and their pigment signatures. In: S. Jeffrey, R. Mantoura, S. Wright (eds.). Phytoplankton pigments in oceanography: Guidelines to modern methods. Paris, France: UNESCO Publ., pp. 37-84.

Jeffrey, S.T., Humphrey, G.F. (1975). New spectrophotometric equations for determining chlorophylls $a$, $b, c 1$ and $c 2$ in higher plants, algae and natural phytoplankton. Biochemie und Physiologie der Pflanzen, 167(2), 191-194. DOI: 10.1016/S0015-3796(17)30778-3

Kearns, K.D., Hunter, M.D. (2000). Green algal extracellular products regulate antialgal toxin production in a cyanobacterium. Environmental Microbiology, 2, 291-297.

Keating, K.I. (1978). Blue-green algal inhibition of diatom growth: transition from mesotrophic to eutrophic community structure. Science, 199, 971-973. DOI: 10.1046/j.1462-2920.2000.00104.x

Klekot, L. (1980). Zatoka Pucka osobliwością hydrologiczną Bałtyku. Oceanologia, 12, 109-123. [In Polish]

Kuczyńska, P., Jemioła-Rzemińska, M., Strzałka, K. (2015). Photosynthetic pigments in diatoms. Marine drugs, 13(9), 5847-5881. DOI:10.3390/md13095847

Mazur-Marzec, H., Sutryk, K., Kobos, J., Hebel, A., Hohlfeld, N., Błaszczyk, A., Toruńska, A., Kaczkowska, M.J., Łysiak-Pastuszak, E., Kraśniewski, W., Jasser, I. (2012). Occurrence of cyanobacteria and cyanotoxin in the Southern Baltic Proper. Filamentous cyanobacteria versus single-celled picocyanobacteria. Hydrobiologia, 701, 235-252. DOI: 10.1007/s10750-012-1278-7

Olenina, I., Hajdu, S., Edler, L., Andersson, A., Wasmund, N., Busch, S., Göbel, J., Gromisz, S., Huseby, S., Huttunen, M., Jaanus, A., Kokkonen, P., Ledaine, I. Niemkiewicz, E. (2006). Biovolumes and size-classes of phytoplankton in the Baltic Sea HELCOM. Baltic Sea Environmental Programme, 106.

Olli, K., Klais, R., Tamminen, T., Ptacnik, R., Andersen, T. (2011). Long term changes in the Baltic Sea phytoplankton community. Boreal Environmental Resources, 16, 3-14.

Pliński, M. (1980). Glony zatoki Gdańskiej: klucz do oznaczania gatunkow. Gdańsk: Wydawnictwo Uniwersytetu Gdańskiego. [In Polish]

Pliński, M., Picińska, J. (1985). The dynamics of seasonal change of the phytoplankton biomass in the Gulf of Gdańsk, Oceanologia, 23, 77-83.

Suikkanen, S., Laamanen, M., Huttunen, M. (2007). Long-term changes in summer phytoplankton communities of the open northern Baltic Sea. Estuarine, Coastal and Shelf Science, 71, 580-592. DOI: 10.1016/j.ecss.2006.09.004

Wasmund, N., Nausch, G., Matthäus, W. (1998). Phytoplankton spring blooms in the southern Baltic Sea-spatio-temporal development and long-term trends. Journal of plankton research, 20, 1099-1117. DOI: $10.1093 /$ plankt/20.6.1099

Żmijewska, M.I., Niemkiewicz, E., Bielecka, L. (2000). Abundance and species composition of plankton in the Gulf of Gdansk near the planned underwater outfall of the Gdansk-Wschod (Gdansk-East) sewage treatment plant. Oceanologia, 42, 335-357. 
The Puck Bay is an area characterised by specific hydrodynamic conditions that determine the distribution and composition of phytoplankton. The aim of this study was to investigate the differences in the phytoplankton composition and the content of photosynthetic pigments between the Puck Bay and open Baltic Sea. The material was collected from four stands which were localised in the inner and outer part of Hel Peninsula. In this study, it has been demonstrated that the composition of individual species of phytoplankton differed between stands in the inner and outer part of the Puck Bay. This investigation has also shown that the number of phytoplankton taxa was similar in three stands and it was much lower on the last stand (Stand 4). The differences in the concentration of photosynthetic pigments between all stands have also been observed.

Key words: phytoplankton, Puck Bay, Southern Baltic Sea, blooms

Received: [2017.07.04]

Accepted: [2017.10.26]

\section{Struktura fitoplanktonu w Zatoce Puckiej oraz na otwartym Morzu Bałtyckim}

Streszczenie

Zatoka Pucka jest obszarem charakteryzującym się specyficznymi warunkami hydrodynamicznymi, które determinują rozmieszczenie i skład fitoplanktonu. Głównym celem niniejszej pracy było zbadanie różnic w składzie taksonomicznym fitoplanktonu oraz zawartości barwników fotosyntetycznych pomiędzy Zatoką Pucką, a otwartymi wodami Morza Bałtyckiego. Materiał zebrano z czterech miejsc zlokalizowanych po wewnętrznej, jak i zewnętrznej, części Półwyspu Helskiego. W pracy wykazano, że istnieją różnice w składzie taksonomicznym fitoplanktonu między wewnętrzną i zewnętrzną częścią Zatoki Puckiej. Niniejsza praca pokazała, że liczba taksonów fitoplanktonu na stanowiskach 1, 2 i 3 była zbliżona i znacznie wyższa niż na stanowisku 4. Zaobserwowano również różnicę w stężeniach barwników fotosyntetycznych między badanymi stanowiskami.

Słowa kluczowe: fitoplankton, Zatoka Pucka, Morze Bałtyckie, zakwity

\section{Information on the authors}

\section{Klaudia Świacka}

In her studies, she focuses on the impact of the Non-steroidal anti-inflammatory drugs on the Baltic benthic fauna. In current laboratory research, she is investigating the bioaccumulation of diclofenac in Mytilus trossulus tissues. Moreover, she determined the occurrence and concentration of NSAIDs in the Gulf of Gdańsk in the water, sediment, and in the tissues of the organisms collected from different stations. She is also interested in the taxonomy of marine organisms and would like to improve her knowledge and skills during future investigations.

\section{Alicja Michnowska}

In her research, she is interested in marine ecotoxicology, especially in the matter of marine invertebrates. Her main interests include the calibration and modification of methods for the determination of biochemical compounds that can serve as potential biomarkers for environmental condition including genotoxicity, metal contamination, and climate changes. The aim of her work is to determine a suitable methodology for a multiple biomarker approach usable in ecotoxicologic studies as an environmental diagnostic tool.

\section{Jakub Maculewicz}

The field of his interest is allelopathic interactions of phytoplankton, in particular, of Baltic filamentous cyanobacteria. He is investigating what influences of allelopathic compounds have on those organisms. In 
his studies, he uses the following innovative methods: analysing pigment content, chlorophyll $a$ fluorescence, and measuring the rate of photosynthesis to determine what impact allelochemicals have on algae.

\section{Izabela Przednowek}

The main area of her interest is the biology and ecology of zooplankton. Currently, her research focuses on comparing the species composition of phyoplankton before and after the inflow of water from the North Sea. Such studies have not been conducted previously in the Baltic Sea.

\section{Iga Ogrodowczyk}

She is a marine biology student, and the main research objective of her bachelor's thesis was to test GST as a marker of neoplasia diseases in bivalve molluscs. Currently, she is trying to expand her knowledge on this subject. She also investigates the spread of neoplasia in bivalve molluscs from the Gulf of Gdańsk.

\section{Sebastian Kozic}

He studies Marine Biology. From the beginning of these studies, he has been interested in investigating zoobenthos. He wrote his undergraduate thesis about polychaetes, and his master thesis will also be about polychaetes. He believes that, in a few years, he will be an expert in polychaetes. 